\title{
Embryonic and Larval Development of Freshwater Fish
}

\author{
Faruk Aral ${ }^{1}$, Erdinç Şahınöz ${ }^{2}$ and Zafer Doğu ${ }^{2}$ \\ ${ }^{1}$ Niğde University, Bor Higher School for Business, Bor/Niğde, \\ ${ }^{2}$ Harran University Bozova Vocational High School, \\ Department of Fisheries, Bozova, Sanliurfa \\ Turkey
}

\section{Introduction}

During the past few years the natural population of the freshwater fishes has been rapidly declining due to various man-made and natural causes. According to IUCN (2000), among 266 species, 14 are going to be extinct, condition of 12 has been severely deteriorated and 28 of them are critically endangered. Moreover, the fish are also under threat due to drying up of the low lying areas and indiscriminate use of fertilizers and pesticides. There is no sufficient information on the early development of the freshwater fishes. So it is necessary to undertake proper study to characterize its various stages of embryonic and larval development to understand the biological clock and cultural techniques of these species (Rahman et al, 2009).

Embryonic studies support phylogenetic development by presenting supportive proofs to determine an organism's ancestral forms. For example, it describes evolutionary development by explaining many issues like gill cleft in the lower vertebrates (fish) which is seen in almost all mammalian embryos in early developmental stages. In addition, this period of fish life is also used in various experimental studies; especially in aquaculture as well as toxicological studies (Rahman et al, 2009).

Life starts with the unification of male and female gametes. As soon as the egg is fertilized by a sperm, the zygote is formed and embryonic development starts and ends up at hatching. The hatchlings further undergo organogenesis and appear as like as their parents, thus end the larval stages. Egg development in the ovary is maternally derived and is predetermined in the ovary but its genetics complex is determined at the very instant of fertilization (Rahman et al, 2009).

In this section, embryonic and larval developments of freshwater fish were examined. Female fish used for egg production and the hormones using for the egg production mentioned in the text, and then fertilization phase which is the first foundation of the creature and some environmental factors affecting this process are described.

In this context, after the fertilization formation of freshwater fish, the embryonic developmental stage, fertilized egg, cleavage, morula, blastula, gastrula, embryonic body formation, optic vesicle and auditory vesicle formation, blastopore closing, tail formation and hatching stages were examined. In the period of larval development after hatching, until the end of the yolk sac absorption period (pre-larvae) and subsequently until the end of metamorphosis (postlarval) formations are shown. 


\section{Determining the methods of larval development}

I wonder if there are different stages in fish lives? To understand this it is needed to observe the life stages of fish. The life stages of fish is formed of 5 stages (Demir, 2006).

1. Embryonic Phase

2. Larval Phase

3. Fry Phase

4. Ripe Phase

5. Senescent Phase

1. Embryonic Phase: It is the stage which start from insemination of egg to the end of vitellus' absorbtion. The period between fertilization of egg and outlet of organism is called incubation period. This is called aclation. Incubation ends with hatching. For that purpose egg capsule is softened with some kind of chemicals and enzymes and these are generallly excreted by ectodermal glands which are situated on anterior face of embryo or some glands on pharynx. Factors like increasing of heat and light increases the activities of embryo and embryo comes out from softened capsule with these chemicals. Embryo always comes out with head and front part of the body. Tail comes out at last and pushes to make embryo come out easier (Langeland and Kimmel., 1997).

It is divided into two:

a. Embryo stage in egg

b. Embryo stage outside the egg

The general characteristic of embryonic stage is being fed by vitellus which is an alternate nutrient.

The embryonic stage, may refer to different stages in eggs. Stages of embryonic development in eggs varies according to different species can be summarized as follows: fertilized egg, cleavage, morula, blastula, gastrula, embryonic body formation, optic vesicle and auditory vesicle formation, blastopore closing, tail formation and hatching stages. In the period of larval development after hatching, until the end of the yolk sac absorption period (pre-larvae) and subsequently until the end of metamorphosis (postlarval) formations are shown (Langeland and Kimmel., 1997).

The stages of embryonic development of Şabut (Barbus grypus H, 1843) and Masopotamian spiny eel (Mastacembelus mastacembelus B\&S, 1794) were given as following (Şahinöz et al., 2006; Şahinöz et al., 2007).

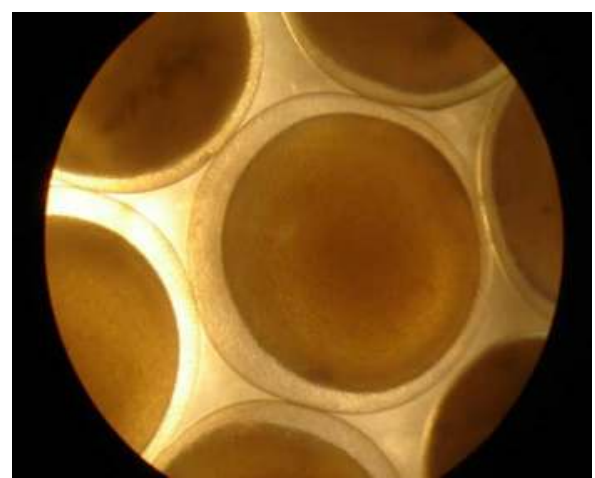

Fertilized eggs and perivitellin space formation after the fertilization. (Barbus grypus H, 1843) 


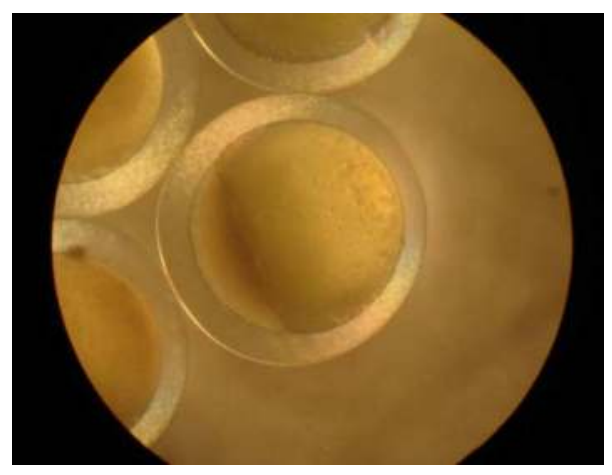

Germinal disc formation (x10). (Barbus grypus $\mathrm{H}, 1843$ )

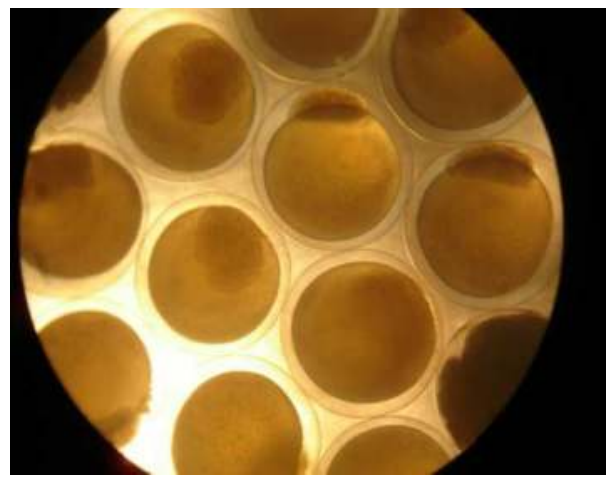

Morula phase and blastomer formation (x10). (Barbus grypus $\mathrm{H}, 1843$ )

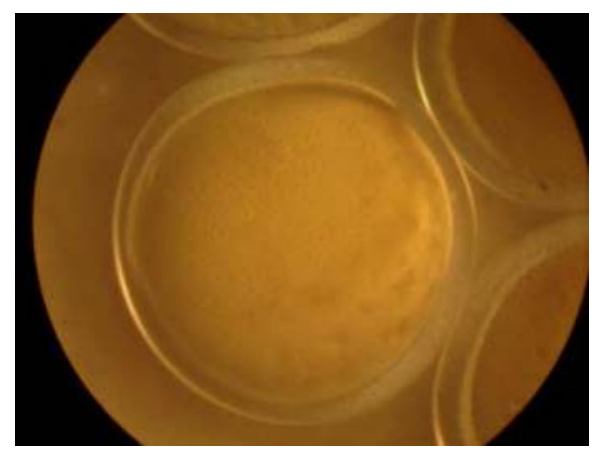

Gastrula phase (x10). (Barbus grypus H, 1843) 


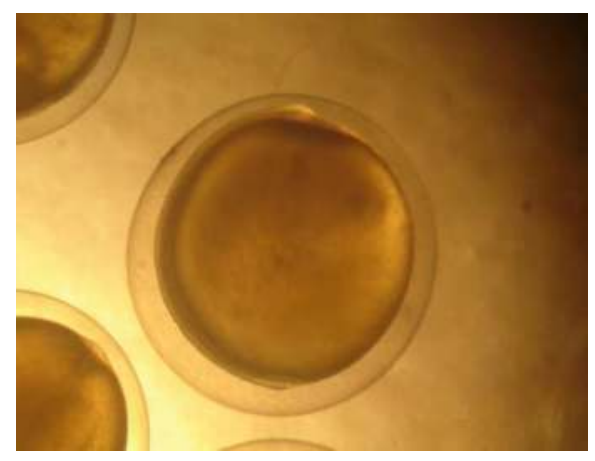

Embryonic body formation (x10). (Barbus grypus $\mathrm{H}, 1843$ )

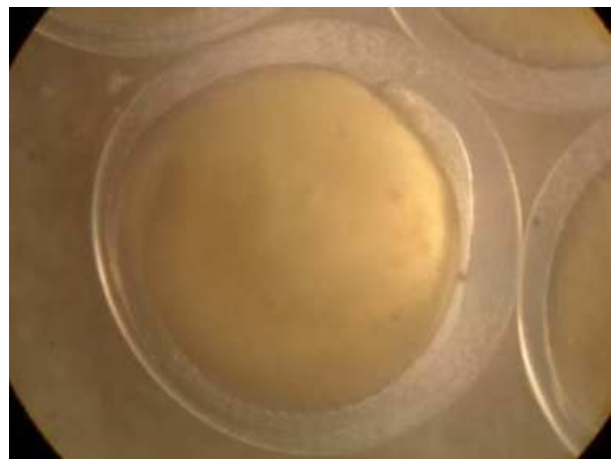

Head formation (x10). (Barbus grypus $\mathrm{H}, 1843$ )

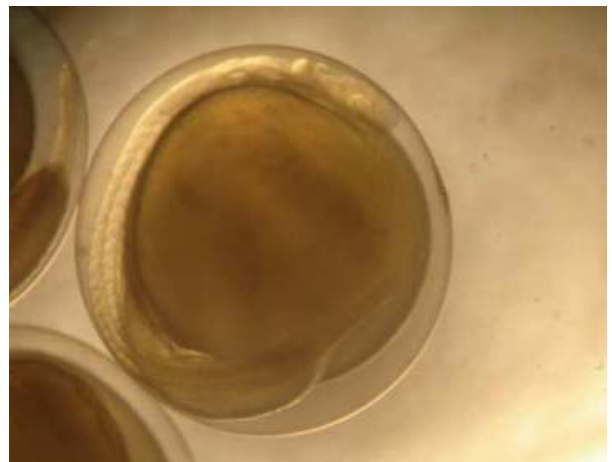

Eyes and otic vesicle formation. (Barbus grypus $\mathrm{H}, 1843$ ) 


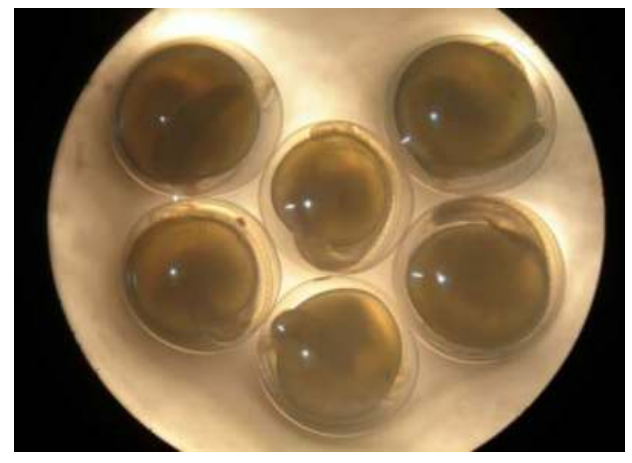

First heart beat and movement (x10). (Barbus grypus $\mathrm{H}, 1843$ )

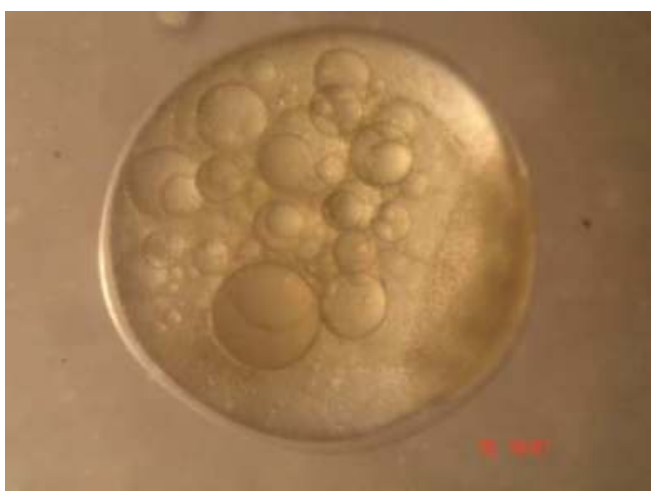

Perivitelline space formation of M. mastacembelus (Bank\&Solender, 1794) (x10).

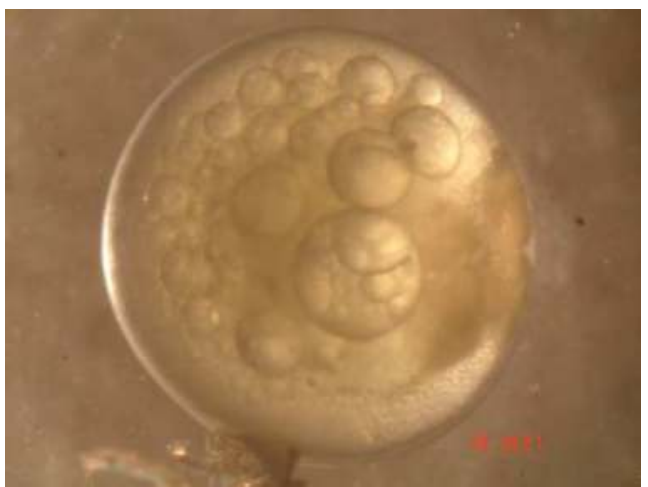

First division in egg cell $(x 10)$. 


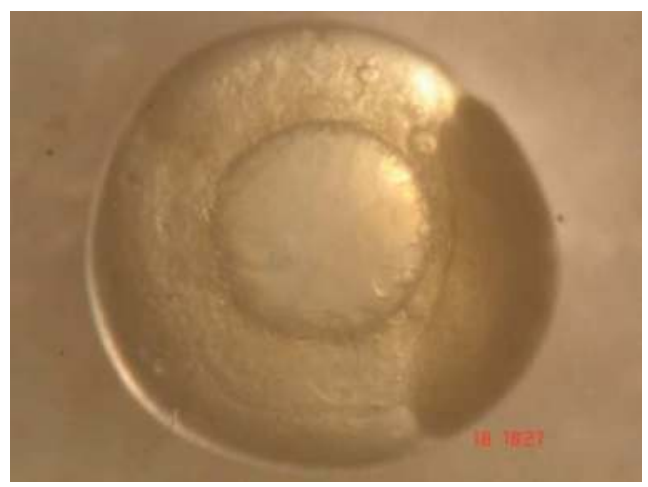

1 oil droplet formation (x10).

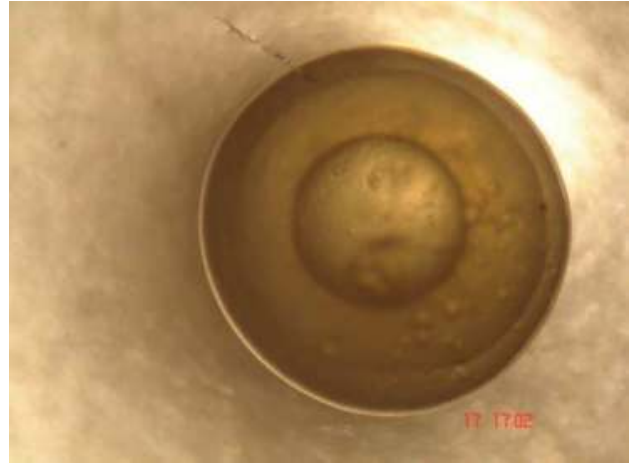

Embryonic shield formation (x10).

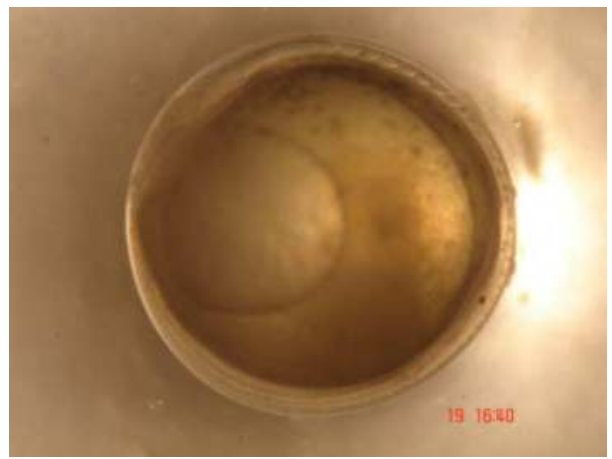

Embryonic body formation and notocorda (x10). 
2. Larval Phase: During the larval stage which follows embryonic stage, nutrition occurs outside. Larvae as the general appereance may differ from mature in many ways in both outer and iner structure. After coming out from the egg, especially teleosts gothrough some stages. These stages are named differently by different scientists. The most common among them is one which Hubbs (1934) proposed. There are 3 phases of fish from coming out egg to fry stage.

- 2.1.Prelarval Phase

- 2.2.Postlarval Phase

2.1 Prelarval Phase: It is the period which starts from coming out from egg to the end of absorbtion of yolk sac. The most important charecteristic of prelarval stage is the existence of yolk sac. This yolk sac is located in anterior and ventral of the body. At the beginnig of tje prelarval phase mouth, anus and digestive tube is like straight pipe. Head is smaller then body, eyes are big and nonpimented. The double-walled sacs in the form of external sensory organ of balance otoliths are on both sides of the head. Nostrils are not developed under eye. Towards the end of this phase mouth and anus opens. Eyes are pigmented and nutrition mouth starts at the outside part. During prelarval phase only the pectoral fins which appears in adults. This draft is positioned horizontally first, then becomes vertically by the progress. Promordial fin remains the surface pelajik by increasing the surface and consists of two layers of skin bend. This double layer of skin is called the space between the subdermal space. In some species after completin prelarval phase and taking the characteristic shape of adult called alevin in Salmonidae fishes. Postlarval stage followed by the majority of the fish prelarval phase.

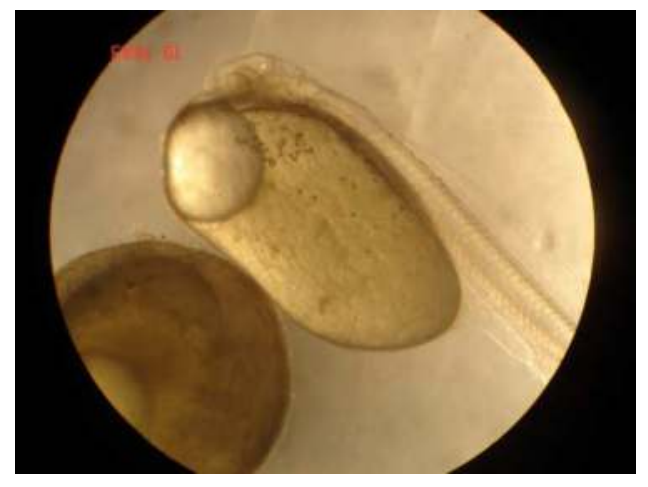

A newly hatched larva. (M. mastacembelus B\&S, 1794) 


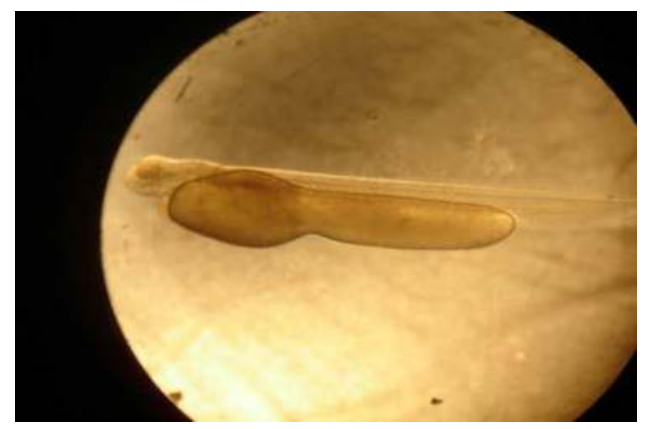

A newly hatched larva. (Barbus grypus $\mathrm{H}, 1843$ )

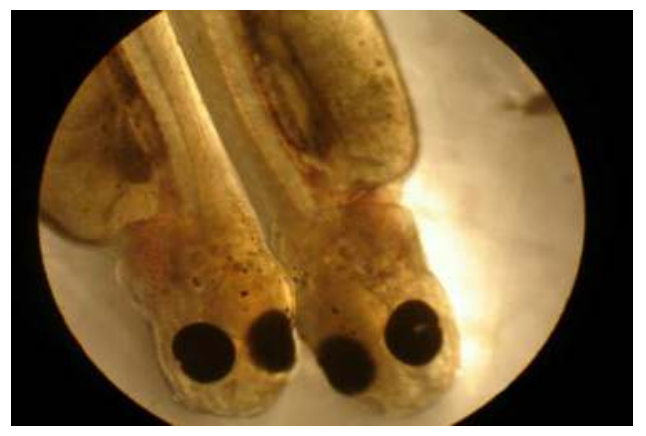

Air bladder formation (x10). (Barbus grypus $\mathrm{H}, 1843$ )

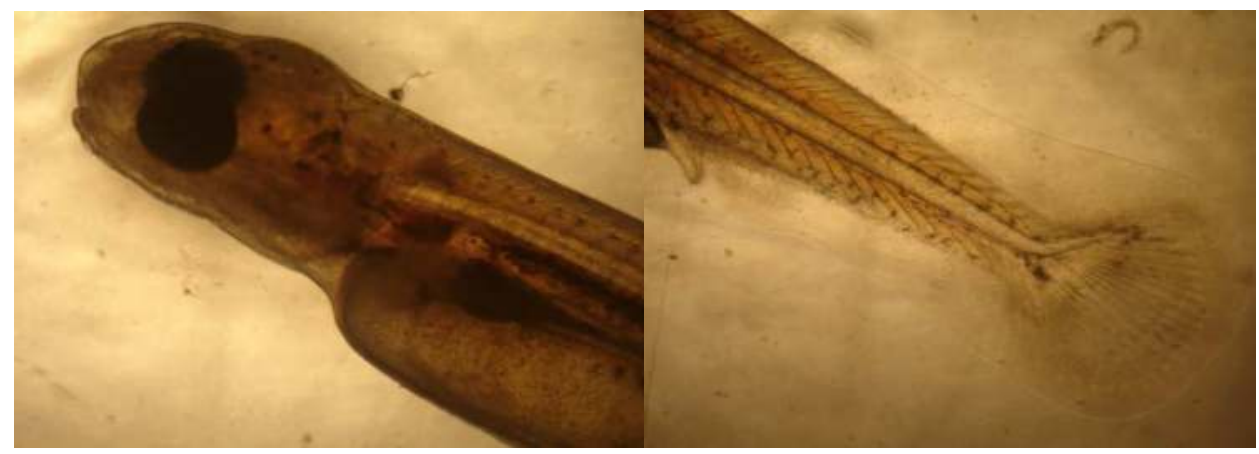

Mouth openning, anus and tail formation (x10). (Barbus grypus H, 1843) 
2.2 Postlarval Phase: It is the time starts after absorbtion finished to the end of metamorphosis. The length of the time changes species to species. It varies to species according to shape, size, body ratio, fin size, pigmentation in different sizes and order, shape and time of organ formation in postlarval phase. Some organs form in postlarval phase in order to make easier to stay pelagic. Nutrition takes place entirely from outside in postlarval phase. Nutritions are fitoplancton, zooplancton or mixture of both.

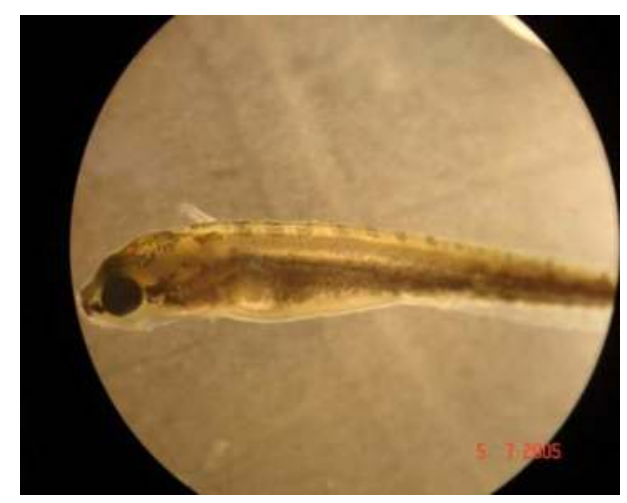

Blood vessel, digestion channels, anus. (M. mastacembelus B\&S, 1794)

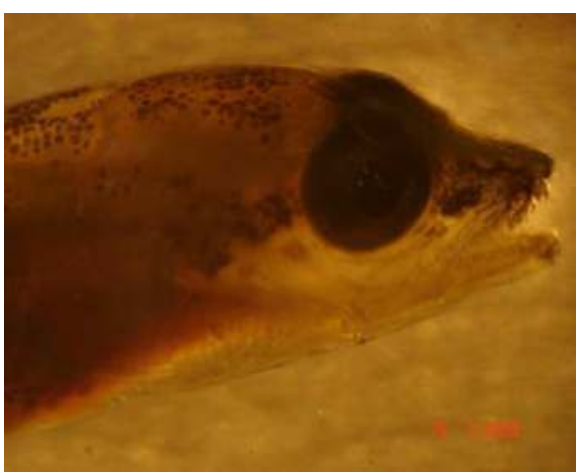

Mouth openning. (M. mastacembelus B\&S, 1794) 


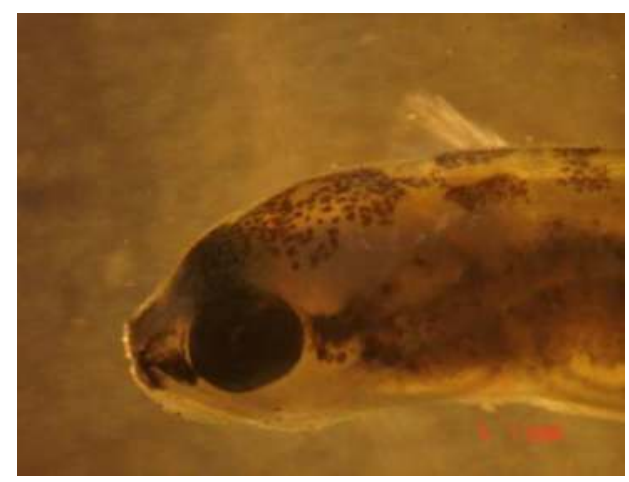

Pigmentation. (M. mastacembelus B\&S, 1794)

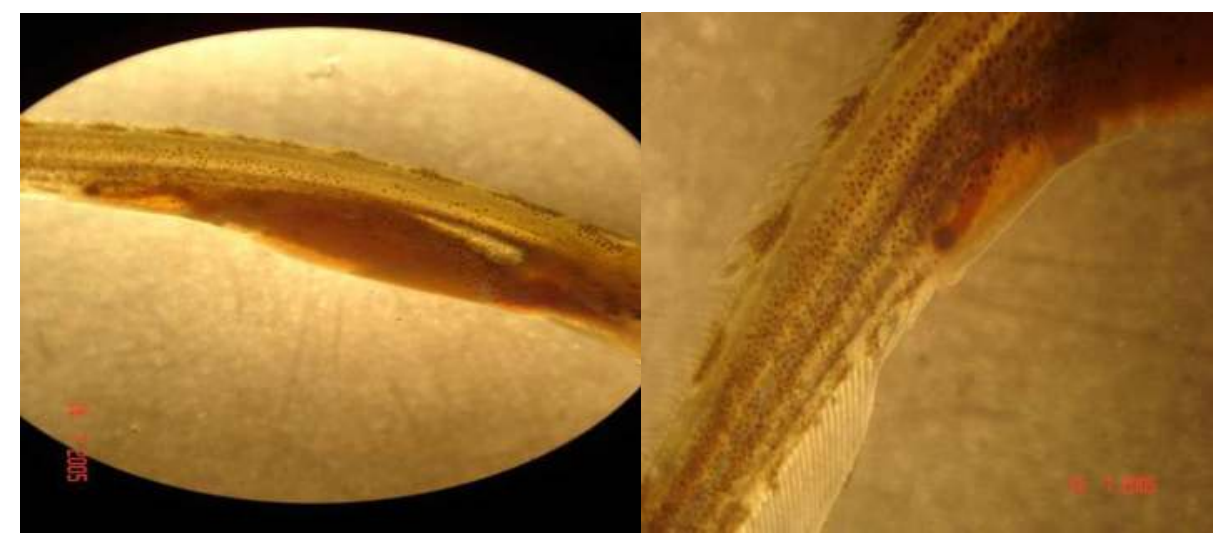

Development of visceral organs. (M. mastacembelus B\&S, 1794)

3. Fry Phase: At the end of post larval phase youth phase starts. Except mugillidae family at other teleosts formation of scales determine the result of postlarval phase. Formation of scales shows the first phase of youth phase. Scales start to develop early. The other event is developing of lateral line. This can be seen at the end of postlarval phase and during metagenezis. Circulation system is formed in many species. The first view of hemoglobine developes during metamorphosis again. Organism is a litlle copy of the mature in youth stage. However some differences are observed in body ratios and colour. In gonads secondary characters does not exist yet if there are. Like in salmonidae some species do not show remarkable metamorphosis during postlarval phase and the individuals belong to this family pass to youth phase directly. At the end of post larval phase with the completion of metamorphosis fish has the ability to move freely and passed to nekton from plancton now on. 4. Ripe Phase: Fish gonads are fully developed and have capability to reproduce capability at intervals. Secondary characters are developed in some fish species (if any).

5. Senescent Phase: Firstly sexual activities decreases then completely disappears. Similarly the growth of height slows down or stops. 


\section{Conclusion}

A fundamental goal in population dynamic is to understand the processes that influence which individuals survive through to reproduction. Mortality schedules are closely linked to the life-history characteristics of the organism and its mode of reproduction (Stearns 1992).

Organisms with complex life cycles, such as insects, marine invertebrates and fishes, have mortality schedules that often approximate exponential decay functions (Hunt and Scheibling 1997). For many of these marine organisms, over $99 \%$ of individuals die prior to metamorphosing to the juvenile state (Gosselin and Qian 1997). A key factor influencing dynamics of these populations is the variation in abundance of juveniles entering the population (Stearns and Koella 1986). However, the processes that govern success during this transition are complex and not fully understood.

From the moment of conception, individuals vary in development and growth rates that will pre-dispose some individuals to a lower probability of surviving later developmental stages.

Fisheries biology is investigating a fish stock in short and in terms of fisheries biology it is important to know the egg and larva. Because these kind of studies are important to determine the spawning seasons and areas, to determine the temporal changes of the spawning season, to predict the ovulating mature stock size, to predict the rate of death of at the end of spawning period and to examine the relation with environment (Yüksek ve Gücü, 1994).

\section{References}

Erdinç Şahinöz, Zafer Doğu, Faruk Aral, 2006. Development of Embryos in Mastacembelus mastacembelus (Bank\&Solender, 1794) (Mesopotamian Spiny Eel) (Mastacembelidae). Aquaculture Research. Blackwell Science, 37 (16): 1611-1616.

Erdinç Şahinöz, Zafer Doğu, Faruk Aral, 2007. Embryonic and Pre-larval Development of Shabbout (Barbus grypus H.). The Israeli Journal of Aquacultre. Bamidgeh. 59 (4): 236-239.

Gosselin, L. A. and Qian, P. 1997. Juvenile mortality in benthic marine invertebrates. Mar. Ecol. Prog. Ser., 146: 265-282.

Hubbs, C. L. 1934. Terminology of early stages of fishes. Copeia, 260.

Hunt, H. L. and Scheibling, R. E. 1997. Role of early postsettlement mortality in recruitment of benthic marine invertebrates. Mar. Ecol. Prog. Ser., 155: 269.

IUCN, 2000. Red Book of Threatened Fishes of Bangladesh. 116.

Langeland, J. and C. B. Kimmel. 1997. The embryology of fish. In S. F. Gilbert and A. M. Raunio (eds.), Embryology: Constructing the Organism. Sinauer Associates, Sunderland, MA, 383-407.

Necla Demir, 2006. İhtiyoloji, Nobel Yayın, Ankara, 252.

Rahman, M.M., Miah, M. I., Taher, M. A., Hasan, M. M. , 2009. Embryonic and larval development of guchibaim, Mastacembelus pancalus (Hamilton) J. Bangladesh Agril. Univ. 7 (1): 193-204. 
Stearns, S. C. and Koella, J. C. 1986. The evolution of phenotypic plasticity in life-history traits: predictions of reaction norms for age and size at maturity. Evolution. 40: 893913.

Yüksek, A. Ve Gücü, A.C., 1994. Balık Yumurtaları Tayini İçin Bir Bilgisayar Yazılımı (Karadeniz Pelajik Yumurtaları), Karadeniz Eğitim-Kültür ve Çevre Koruma Vakfı, İstanbul, 51. 


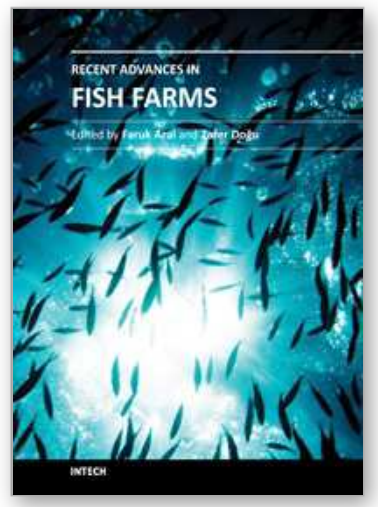

\author{
Recent Advances in Fish Farms \\ Edited by Dr. Faruk Aral
}

ISBN 978-953-307-759-8

Hard cover, 250 pages

Publisher InTech

Published online 21, November, 2011

Published in print edition November, 2011

The world keeps changing. There are always risks associated with change. To make careful risk assessment it is always needed to re-evaluate the information according to new findings in research. Scientific knowledge is essential in determining the strategy for fish farming. This information should be updated and brought into line with the required conditions of the farm. Therefore, books are one of the indispensable tools for following the results in research and sources to draw information from. The chapters in this book include photos and figures based on scientific literature. Each section is labeled with references for readers to understand, figures, tables and text. Another advantage of the book is the "systematic writing" style of each chapter. There are several existing scientific volumes that focus specially on fish farms. The book consists of twelve distinct chapters. A wide variety of scientists, researchers and other will benefit from this book.

\title{
How to reference
}

In order to correctly reference this scholarly work, feel free to copy and paste the following:

Faruk Aral, Erdinç Şahınöz and Zafer Doğu (2011). Embryonic and Larval Development of Freshwater Fish, Recent Advances in Fish Farms, Dr. Faruk Aral (Ed.), ISBN: 978-953-307-759-8, InTech, Available from: http://www.intechopen.com/books/recent-advances-in-fish-farms/embryonic-and-larval-development-offreshwater-fish

\section{INTECH}

open science | open minds

\author{
InTech Europe \\ University Campus STeP Ri \\ Slavka Krautzeka 83/A \\ 51000 Rijeka, Croatia \\ Phone: +385 (51) 770447 \\ Fax: +385 (51) 686166 \\ www.intechopen.com
}

\author{
InTech China \\ Unit 405, Office Block, Hotel Equatorial Shanghai \\ No.65, Yan An Road (West), Shanghai, 200040, China \\ 中国上海市延安西路65号上海国际贵都大饭店办公楼405单元 \\ Phone: +86-21-62489820 \\ Fax: +86-21-62489821
}


(C) 2011 The Author(s). Licensee IntechOpen. This is an open access article distributed under the terms of the Creative Commons Attribution 3.0 License, which permits unrestricted use, distribution, and reproduction in any medium, provided the original work is properly cited. 